\title{
FOREIGN MISSIONARY CO-OPERA- TION AND UNITY AT THE HOME BASE IN AMERICA
}

\author{
BY CHARLES R. WATSON, D.D.
}

Even though the goal of foreign missionary co-operation lies in foreign lands, the necessity for laying at the home base a foundation for close relationships abroad is obvious. Among the findings of Commission VIII of the Edinburgh Conference is the following :

In regard to the home base our study of the evidence has impressed on us the conviction that the problem which we are considering is not one of which the solution can be solved in the mission field alone. It is one in which the home Church and the home societies are deeply concerned. It is true that in the matter of unity the mission field is leading the way; but it does not seem that the movement can advance far with safety apart from the co-operation of the Church at home.

It is the object of this article to consider the developments of foreign missionary co-operation at the American home base.

It is interesting to note that the foreign missionary movement in America had in its beginning the appearance at least of unity ; it then passed through a period marked by division and separation; since then it has advanced toward a new and larger unity and co-operation. The oldest foreign missionary society in America is the American Board of Commissioners for Foreign Missions, which was organized in 1810 and secured its charter in 1812. The historical relationships of the new board made it distinctively the organ of the Congregational Churches of North America, but there was nothing in its name or constitution to limit it to any one ecclesiastical body. It invited other bodies, 
the General Assembly of the Presbyterian Church in particular, to organize similar societies of their own with which it might co-operate. Accordingly, in 1812, there were appointed eight commissioners for the Presbyterian Church and one from the Reformed (Dutch) Church in America, all of whom sustained voluntary relations with the American Board. This continued for a time, and finally these groups asked to be amalgamated to avoid duplication of organization. What appeared in those early days to be a sort of unity in foreign missionary effort was only accidentally such, for this unity resulted chicfly from the weakness of the missionary movement in its beginning and because the movement needed to draw upon the interest of all those who, regardless of ecclesiastical relationships, were brave enough to defend and support foreign missionary work. As the interest widened, the insistent demand of practical ecclesiastical relations made it necessary to relate the missionary movement to the churches. In 1840, therefore, some thirty years after the launching of the first foreign missionary society, the American Board, there were to be found in the United States and Canada some thirteen different missionary boards, all of whom, save two, were related to distinct ecclesiastical bodies. The only two major boards which did not sustain such relationships were the American Bible Society, founded in 1816, and the American Tract Society in 1825; the latter, however, was not a 'sending' society, that is, one which sent its own agents abroad.

It will be suggestive to notice the number of 'sending' foreign missionary societies organized in the United States and Canada in each decade since the inception of organized foreign missionary effort in 1810. In the table which follows, ' major boards' is meant to represent the missionary board which is generally recognized as the official board excrcising supervision over the whole foreign missionary work of a given denomination or group of persons. By ' minor board' is meant an auxiliary society operating in 
a more restricted field. In some cases home mission boards operating in foreign missionary territory are included.

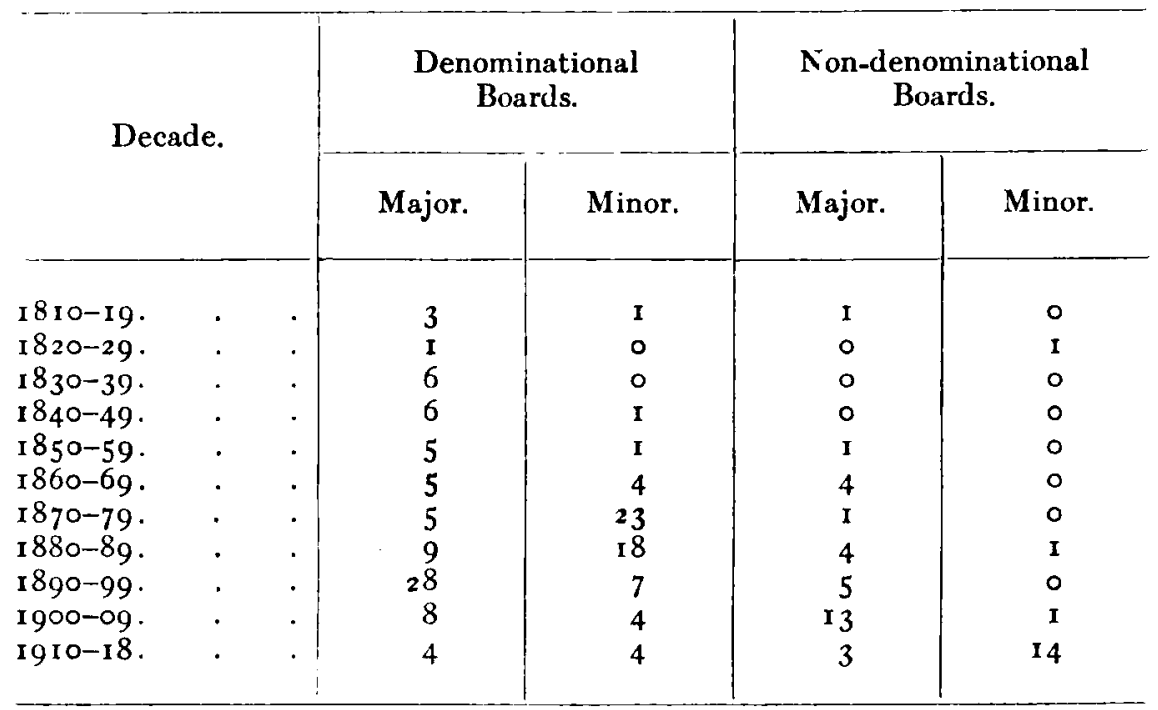

The foreign missionary movement in North America may be said to have moved along denominational lines chiefly. Indeed so fully did the denominational missionary board preoccupy the field, cultivating the interest of its church's constituency, claiming the gifts of its members and holding their allegiance, that only a limited place was left to undenominational or independent missionary organizations. The proportion of non-denominational boards in America which send missionaries abroad is considerably smaller than in other countries. Whatever disadvantage may attach to this line of development it has the advantage of relating to the missionary task more practically and officially the full energies of each ecclesiastical body. It may seemingly lead away from cooperation and unity, but it makes for intensity of effort and administrative efficiency within each organization. Dealing therefore with such a development, unity must be looked for in terms of federation or inter-denominational 
co-operation rather than in terms of independent missionary effort, or organic union.

The spheres within which foreign missionary co-operation has expressed itself and where it has been found most practicable at the home base in America, are the following :

Conferences. Obviously, the spirit of co-operation does not need to be very fully developed to make a conference possible. Without implying compromise or concession of any sort, independent agencies can afford to come together for conference. It is the most elementary form of co-operation. On the other hand, a conference does present remarkable possibilities for the cultivation of the fraternal spirit. A conference brings with it personal acquaintance, mutual understanding and a unifying of aims. Special reference will be made presently to conferences and similar associations at the American home base which have a permanent character and which meet at least annually. But in addition to these, special conferences are constantly being called, and the increasing number of these bears proof to a growing spirit of unity and co-operation. Some are conferences of agencies labouring in the same mission field, such as the recent conference on Africa, where twenty-four different American missionary agencies labouring in Africa came together to discuss during two full days their common problems, or such as the conference held in 1914 when the missionary agencies working in Mexico met, and as a result of their meeting a most remarkable program of co-operative effort was adopted, involving even a redistribution of the field.

Research. Special surveys, general missionary research and investigations of special problems have afforded another favourable field for missionary co-operation at the American home base. The Home Missions Council has had several such surveys, such as those of rural fields and of neglected fields. The foreign missionary agencies have co-operated in the support of the survey work of the Rev. W. H. Findlay 
in India and somewhat similar surveys in China and Japan, in addition to the very comprehensive survey of South America made in preparation for the Panama Congress. The need for a research library and a research bureau to render most effective such investigation became insistent, so a few years ago it was decided to establish a fund to which all mission boards might contribute, and to which the Rockefeller Foundation has also made a generous grant, for the establishment, among other things, of a Missionary Research Library. This library, located in New York, is now the largest missionary library in the United States for research purposes. It contains over 15,000 books and bound volumes of reports and 4000 counted and listed pamphlets; it receives 200 periodicals and has partial or complete files of 641 others. It is becoming a depository for original material and missionary manuscripts which individuals or societies desire to see preserved.

As a necessary adjunct of this same development there is the Research Bureau. This bureau has hitherto limited itself largely to the gathering of home base statistics and has also made and published a Quinquennial Statistical Survey of Missions in all lands, bringing down to 1915 the statistical work presented to the Edinburgh Conference in 1910. The bureau's activities are constantly widening, as it undertakes to answer the increasing stream of inquiries coming in from students of missions in America, or as it makes special surveys for conferences called to take up special questions.

Missionary Literature. It is a short step from co-operation in missionary research to co-operation in missionary publication. For years there has been such co-operation as is represented in the publications of the Missionary Education Movement and the Laymen's Missionary Movement. The text-books for the study of missions published in part by the Missionary Education Movement have been widely used by all churches and 
boards. The Committee of Reference and Counsel has also been issuing for mission boards a series of pamphlets distributed only to pastors and church leaders, which represent co-operation in an extremely specialized field. It must be confessed, however, that in proportion to the total amount of literature issued in connexion with the foreign missionary movement the amount issued under interdenominational auspices is comparatively small. Co-operation here awaits co-operation in the public appeal for funds, for so long as each agency must make its appeal for funds separately, it seems necessary to give denominational earmark to the literature which goes to a particular constituency.

The Education and Cultivation of the Home Church. This has been the outstanding field for missionary co-operation at the home base. The Missionary Education Movement has been used by the majority of American boards to provide the mission study class movement and to emphasize the study of missions in the Sunday schools. The Laymen's Missionary Movement has been the agency for a number of years through which a similar effort was put forth aimed at reaching the more mature layman and business man. Both these movements have found it an enormous advantage to use the community approach and to make appeal to the corporate spirit and organization which a city or town has developed. There has been a real power in this plan of dealing with a community as a whole.

United Grving. While as yet co-operation in American missionary circles has not gone beyond simultaneous financial campaigns, it will be interesting to note that at the last annual Conference of Foreign Missions Boards the proposal was made that the several foreign missionary boards of America should unite in a 'financial drive,' for some amount to be given into a common treasury to cover the budgets of the boards. The proposal aroused enough interest to be referred to the Committee of Reference 
and Counsel for special consideration. The committee did not feel that the time was ripe for such an advanced step in co-operation. Since that time, however, the war situation has forced just such a co-operative financial effort among the welfare agencies labouring in the military camps. Thus we see the Young Men's Christian Association, the Salvation Army, the National Catholic War Council and the Jewish Welfare Board, together with some others, uniting at the request of the President to raise $\$ 170,000,000$. When a union effort of such a character becomes possible in a sphere not wholly removed from the religious, the union of Presbyterian and Methodist and Baptist and the rest of the larger denominations in a great financial campaign with a common treasury can no longer be rejected as unthinkable.

Recruiting and Training Candidates. Practically all American foreign missionary societies maintain a more or less formal candidates' department. Nevertheless, cooperation has gone to great lengths in the recruiting of candidates under the auspices of the Student Volunteer Movement. This movement has increasingly sought to adjust its methods of work so as to effect a vital connexion between the students who volunteer for missionary service, often in response to a wholly general appeal, and the particular foreign board to whose church the volunteer belongs.

The Board of Missionary Preparation, organized by the foreign mission boards of America to meet their common needs, deals with the problem of special training for foreign missionary service. Unlike the similar organization in Great Britain, the American Board of Missionary Preparation has not attempted to develop any central training school for missionary candidates. Rather has it sought to develop a body of literature and with it a body of missionary opinion setting forth the ideals for missionary preparation. The hope is that thus will missionary candidates everywhere by their demands, and theological and 
missionary training schools everywhere by their provision of suitable courses, undertake to realize these ideals.

Representations to Governments. In negotiating with their own or other governments, American foreign missionary boards have appreciated the advantage of united representation, and at times the necessity for it. The Committee of Reference and Counsel, under its two able chairmen, the Rev. A. J. Brown, D.D., and the Rev. J. L. Barton, D.D., has repeatedly served the missionary boards in making such representation. During the past year alone, the Sub-committee on Missions and Governments has had to take up such governmental questions as passports, regulations, permits to leave the country, compensations for losses caused by the war, military draft regulations, Turkish abolition of the Capitulations, anticlerical laws in Mexico and the conscience clause in India.

Conference of Foreign Mission Boards. Tracing co-operative effort in America to its source, it will be found ordinarily to have received its impulse from one of two sources. Some natural or enforced relationship in a field of work has revealed the advantage of cooperation; or some conference has inspired the idea. It is a generally recognized fact that following upon such historic gatherings as the Ecumenical Convention of 1900 in New York and the Edinburgh Conference of 1910, proposals for co operation in foreign missions appeared in almost every sphere and field of missionary activity. In the life of the American foreign missionary movement, the annual Conference of Forcign Missions has perhaps played the largest part in promoting co-operation and unity. This conferener first met in New York in $\mathbf{1 8 9 3}$ upon the suggestion of a resolution passed the previous year by the Council of the Presbytcrian and Reformed Alliance. It is worth noting that it was a gathering representing close $\mathrm{r}$ ccclesiastical relationship that brought into existence the conference that has so profoundly advanced practical co-operation in forcign missionary administration. 
This is as it should be. Ecclesiastical co-operation becomes actual only as it is realized in administrative spheres; and missionary co-operation ought to have behind it a spirit of co-operation between the churches represented. Although the conference called into being in 1893 had a representation at the first meeting of twenty-one different missionary organizations and an attendance of sixty-eight, it was evidently regarded in the nature of an experiment and not for several years did it become a permanent annual gathering. At the twenty-fifth meeting of the conference in 1918, the attendance was three hundred and thirty-one and there were represented seventy-five missionary organizations.

The influence which the annual Conference of Foreign Mission Boards of North America has had upon the missionary movement in America is incalculable. For twentyfive years it has brought together annually the leaders and administrators of the American missionary movement; co-operation and unity are ultimately based on acquaintance. It has also laid hold, for discussion and investigation, of the largest and most important questions of foreign missionary policy and administration; its reports constitute therefore the most important single depository of missionary information and experience in so far as the American missionary movement is concerned. It has across a quarter of a century taken on increasingly such functions and organizations as would enable it efficiently to perform the services which its position and influence impose upon it. Its standing executive committee is called the Committee of Reference and Counsel and is composed of twenty-seven members. The committce is now incorporated under the laws of the state of New York, so that it may receive, hold and administer, subject to the conference, such funds as may be committed to it for co-operative activities. Some idea of the outreach of the missionary co-operation represented by this conference can be gained from the list of sub-committees which have been formed by the Committee of Reference and Counsel 
to care for its work. There are sub-committees on emergencies and reference, missions and governments, finance and headquarters, cultivation of home church, interdenominational and undenominational agencies, principles and methods of missionary administration, relations to similar bodies, the statistical bureau, the research library, and on arrangements. The annual budget which the Committee of Reference and Counsel administers in the name of the conference amounts to $\$ 70,000$.

Only a careful study of the twenty-five printed reports of this conference would make possible a full appreciation of the service that it has rendered. Among the more outstanding services that might be mentioned are the following: The conference has served as a clearing house for American missionary interests and its Committee of Reference and Counsel has served as an agency through which the American missionary movement as a whole might express itself and be represented. It has served as an efficient bit of interdenominational machinery for the promotion of such gatherings as the Ecumenical Conference in 1900, the Edinburgh Conference in 1910 and the Panama Congress in 1916. It is doubtful whether the first or last of these three important gatherings could have been realized without the Foreign Missions Conference. It has also placed at the disposal of the American foreign missionary movement certain useful and important equipment whose provision might not have been possible by any one organization, for example, a mission cable code book, a missionary research library, a bureau of statistical and general research and missionary headquarters where interdenominational meetings and smaller conferences can be held. It has also been responsible for organizing and maintaining and directing a Board of Missionary Preparation whose carefully prepared booklets are invaluable for the recruiting and training stages of the missionary candidate's life. In addition to this it has provided the funds for certain scientific research work in the foreign field, such as 


\section{Missionary Co-operation in America}

the survey in India and the activities of the several national missionary bodies in India, China and Japan. It has provided a suitable representative agency for dealing with large questions and in particular for carrying on negotiations with the Government. By such activities of the utmost practical value and by a policy characterized by conservatism and practical wisdom, it has served to advance the interest of co-operation and unity at the home base in everything that pertains to foreign missions.

While the Foreign Missions Conference is perhaps the agency promoting most directly co-operation and unity at the home base in America, there are other agencies whose activities contribute richly to this same end.

The Home Missions Council. This body, which came into existence in 1908, was organized 'to promote fellowship, conference and co-operation among Christian organizations doing missionary work in the United States, Canada and their dependencies.' It has become an influence working for co-operation and unity even in foreign missionary circles for two reasons.

In the first place, the principles of co-operation and the spirit of co-operation are after all very much the same whether the sphere be foreign missions or home missions. To read, as one may in the 1914 Report, the plan for cooperation as to 'the occupancy of new fields,' ' communities already occupied' and finally as to 'overchurched communities,' and to realize that the principles laid down were not only presented to the council but were adopted by a large number of the constituent churches, is to realize what progress the spirit of co-operation has made in America. The 'National Program in Home Missions' presented to the council in 1918 contains the following paragraph :

Whereas the evils of sectarian friction and duplication are deplored by all who labour for the advancement of the kingdom of God in American society and abroad, and

Whereas every consideration of constructive and forward-looking church 
statesmanship requires the marshalling of resources in far-reaching co-operative programs.

Could anything be more conducive to co-operation and unity in foreign missionary circles than to have such points of view adopted and such principles enunciated in home missionary circles?

In the second place, the task of home missions in America is, at many points, identical with that of foreign missions. When home mission boards extend their activities to the dependencies of the United States or lands contiguous they are touching foreign missionary areas, as in the case of Mexico, Cuba, Porto Rico, Panama and the Philippines. In addition to this, the problems of home missions on the North American continent are in many respects foreign in type, as in the case of the Indians, the Negroes and the immigrants. Co-operation in such work promotes co-operation in foreign missionary circles at the home basc.

The Federal Council of the Churches of Christ IN America. This body, fully organized since 1908, has as its aim 'to manifest the essential oneness of the Christian churches in America in Christ as their Divine Lord and Saviour and to promote the spirit of fellowship, service and co-operation among them.' Merely to name the permanent commissions of this council is to suggest the powerful influences that it is constantly exerting in the direction of co-operation and to indicate the vital bearing which such an influence has upon co-operation in foreign missionary spheres. Among these commissions are those on evangelism, Christian education, international justice and goodwill, and on relations with the Orient.

The very fact that the Federal Council brings together not merely certain administrative departments of the churches, such as the foreign boards, but brings the churches together as ecclesiastical bodies, provides a splendid and a necessary foundation for effective co-operation between the several committees and boards of these different churches. 
In addition to the emphasis laidin these interdenominational bodies upon co-operation and unity, impulses toward co-operation have come out of the position taken by individual churches and organizations favouring co-operation and unity. The following is an official statement made on behalf of the American Board of Commissioners for Foreign Missions :

The American Board of Commissioners for Foreign Missions has repeatedly committed itself to any and every practical plan of co-operation which was within the limit of its financial resources.

The Presbyterian Board (North) issued the following statement which was subsequently approved by its General Assembly :

Believing that the time has come for a yet larger measure of union and co-operation in missionary work, the board recommends to its missions in various lands that they encourage as far as practicable the formation of union churches, in which the results of the mission work of all allied evangelical churches should be gathered, and that they observe everywhere the most generous principles of missionary comity.

In the General Policy of the American Baptist Board (North) there appears the following statement which was approved by the Northern Baptist Convention :

That to the utmost practical extent there should be co-operation with other Christian bodies working in the same fields. Such co-operation is of special importance in the department of higher education, where students are relatively few and education expensive.

Similar utterances might be quoted from other churches.

As an illustration of the increasing possibility for co-operation and unity, there should be mentioned ecclesiastical unions such as the one being effected by the three separate divisions of the Lutheran Church in America, the General Synod of the Evangelical Lutheran Church in the United States of America, the General Council of the Lutheran Church in North America, and the United Lutheran Church in the South. These three bodies voted to meet in New York on November 14, 1918, to con- 
summate the union which they had approved severally and to organize themselves into the United Lutheran Church in America. Such a union carries with it naturally the union of the foreign missionary agencies of these three bodies.

One further factor in promoting co-operation remains to be named. It is the war. The war has influenced every department of life in America, emphasizing economy, simplification of methods and administration, unity and co-operation. The missionary movement in America has been affected by it. Reference has already been made to the united financial campaign planned for by the Young Men's Christian Association, the National Catholic War Council, the Jewish Welfare Board, the Salvation Army and several other agencies labouring in the American military camps. But the union movement involved reaches further, for a committee representing these several agencies has been formed upon the invitation of the Secretary for War 'to discuss and adjust matters relating to the work of the several organizations which might involve duplication in the expenditure of money and efforts at home and abroad.' With such far-reaching proposals before them, establishing comity and co-operation between agencies so dissimilar in their historic antecedents, it will not be surprising if the thought of unity and co-operation become so familiar and generally accepted that the country will demand a closing up of the ranks among the now separated churches of North America.

In any case, the spirit which makes for co-operation and unity is certainly gaining in strength throughout American Christendom. Men seem unable to get away from the deep conviction that somehow the fulfilment of Christ's last commission, 'Go ye into all the world and preach the Gospel to every creature,' is vitally connected with the realization of Christ's last prayer, 'that they may be one.'

Charles R. Watson 